\title{
RANCANG BANGUN WEBSITE E-LEARNING PROGRAM STUDI PENDIDIKAN JASMANI, KESEHATAN DAN REKREASI JURUSAN ILMU PENDIDIKAN FKIP UNIVERSITAS PALANGKA RAYA
}

\author{
Jadiaman Parhusip ${ }^{\text {a,1,* }}$, Abertun Sagit Sahay ${ }^{\text {b,2 }}$, Antonius Nahak Marin ${ }^{c, 3}$, Giga Kristiantiono ${ }^{\text {b, }}$ \\ ${ }^{a}$ Jurusan Teknik Informatika FT UPR, Jl H. Timang Tunjung Nyaho \\ b Jurusan Teknik Informatika FT UPR, J1 H. Timang Tunjung Nyaho \\ 'Jurusan Teknik Informatika FT UPR, Jl H. Timang Tunjung Nyaho \\ ${ }^{1}$ parhusip.jadiaman@it.upr.ac.id *; ${ }^{2}$ abertun@gmail.com; ${ }^{3}$ a.n.marin@gmail.com ; ${ }^{4}$ giga.k@gmail.com
}

\section{ARTICLE INFO}

\section{Keywords}

Physical Education and

Recreation Study Program

website

e-learning

\section{ABSTRACT (10PT)}

Physical Education and Recreation Study Program is one of Study Programs of Education Stream of Faculty of Teacher and Education of Palangka Raya University. During this time, learning and teaching activity in Physical Education and Recreation Study Program (PJKR) happens with one condition in which there is a meeting between students and lecturer in a class. If the meeting does not happen this means the learning and teaching activity will be interrupted or delayed. To solve the problem of delayed learning and teaching activity, it is needed a certain facility which is available to maximize the learning and teaching process through the development of technology in education area. This is known as website e-learning.

This website was constructed using PHP, database MySQL and also phases of waterfall software development method; Analysis and Definition of Need, System Plan and Software, Implementation and Test of Unit, Integration and Test of System, and Operation and Maintenance.

The result of the blackbox test showed that website e-learning PJKR Program Study could manage feature of e-learning which were lecture materials and assignments or quizes. This e-learning ran well accordance with its design.

\section{PENDAHULUAN}

\subsection{Latar Belakang}

Program Studi Pendidikan Jasmani, Kesehatan dan Rekreasi (Prodi PJKR) adalah salah satu program studi dibawah Jurusan Ilmu Pendidikan, Fakultas Keguruan dan Ilmu Pendidikan Universitas Palangka Raya. Prodi PJKR merupakan salah satu prodi yang didirikan untuk memenuhi kebutuhan bidang pendidikan terutama dalam penyediaan tenaga keolahragaan dilingkungan sekolah atau guru pendidikan jasmani. Prodi PJKR dituntut harus mampu meningkatkan kualitas dan mutu pendidikan yang diselenggarakannya. Salah satu sarana dan prasarana yang menggunakan kemajuaan teknologi yang dapat memaksimalkan proses perkuliahan pada Prodi PJKR adalah website E-learning.

Menurut fungsinya terhadap kegiatan perkuliahan pada Prodi PJKR, E-learning ini dimaksudkan bukan untuk menggantikan keseluruhan perkuliahan tatap muka di ruangan, tetapi untuk membantu mahasiswa dalam mempelajari mata kuliah karena perkuliahan tatap muka tidak dapat terlaksana karena satu dan lain sebab/kendala. 


\subsection{Kajian Literatur}

1. Sejarah dan Perkembangan E-Learning

Pembelajaran elektronik pertama kali diperkenalkan di Universitas Illinois di Urbana Campaign pada 1960 dengan menggunakan sistem instruksi berbasis computer-assisted dengan program komputer yang diberi nama Programmed Logic for Automatic Teaching Operation. ELearning mulai dikenal dan berkembang seiring mulai dikenalnya dan digunakannya komputer secara luas oleh masyarakat terutama oleh kalangan akademisi untuk membantu memecahkan berbagai persoalan di dunia pendidikan maupun dalam kebutuhan sehari-hari. Perkembangan elearning dari masa ke masa diawali pada tahun 1990 pada masa CBT (Computer Based Training) di mana dimulai bermunculan aplikasi E-Learning yang berjalan pada PC stand alone ataupun bentuk kemasan CD-ROM. Isi materi dalam bentuk tulisan maupun multimedia (video, dan audio), dalam bentuk MOV, MPEG-1, atau AVI [1], [2],[3].

\section{Implementasi E-Learning}

Implementasi e-learning di Malaysia dibahas oleh Bullen [4], serta Koran [5], ELearning 2.0 telah dikembangkan oleh Wijaya [6], E-Learning untuk mahasiswa Teknik Informatika Universitas Palangkaraya oleh Marantika dan Syandy [7], E-Learning di Universitas Islam Indonesia (UII) dibahas dan ikut dalam Lomba Karya Tulis Ilmiah di Yogyakarta oleh Anggoro [8], Beam, P. [9] telah membahas efektivitas biaya dalam penyelenggaraan E-Learning dalam Seminar Internasional bertempat di Bali.

\section{Metode Penelitian}

Metode Pengembangan perangkat lunak yang digunakan adalah metode Waterfall [6]. Waterfall model adalah sebuah contoh dari proses perencanaan, di mana semua proses kegiatan harus terlebih dahulu direncanakan dan dijadwalkan. Gambar 1 menunjukkan model waterfall [6].

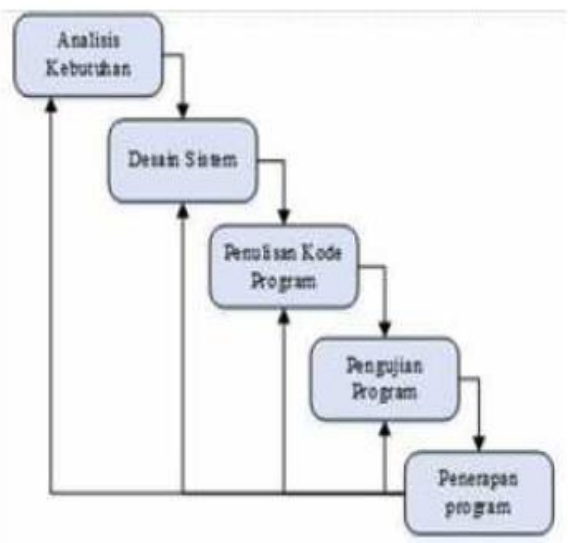

Gambar 1. Waterfall Model

\section{Perancangan Sistem Dan Implementasi}

3.1 Sistem Yang Dikembangkan

3.1.1 Pengguna Website:

1. Admin merupakan pengguna yang memiliki hak akses tertinggi yang dapat melakukan pengaturan terhadap semua fitur yang terdapat pada website.

2. Dosen merupakan pengguna yang memiliki hak akses terhadap fitur-fitur pada E-Learning, meliputi fitur Materi, Tugas/Quiz, Glossary dan forum. 


\section{JURNAL TEKNOLOGI INFORMASI}

[E-ISSN 2656-0321]

[Vol 13. No. 1]

Jurnal Keilmuan dan Aplikasi Bidang Teknik Informatika

3. Mahasiswa merupakan pengguna yang memiliki hak akses terhadap fitur-fitur seperti pada fitur E-Learning, Registrasi, Tugas/Quiz, Glosary, download materi pada Materi, download tugas dan upload hasil tugas pada Assignment.

\subsubsection{Software penunjang:}

1. Photoshop: Untuk mengedit gambar

2. Xamp Web Server:

3. Notepad ++ : Untuk menuliskan coding PHP

4. Dreamweaver: Mendesain tampilan web

5. Browser Firefox: Untuk Browsing web

6. MySQL: Untuk database

\subsubsection{Desain System}

Flowchart yang diusulkan; login untuk mahasiswa (Gambar 2), login untuk dosen (Gambar 3), dan untuk proses mengikuti e-learning (Gambar 4), sebagai berikut.

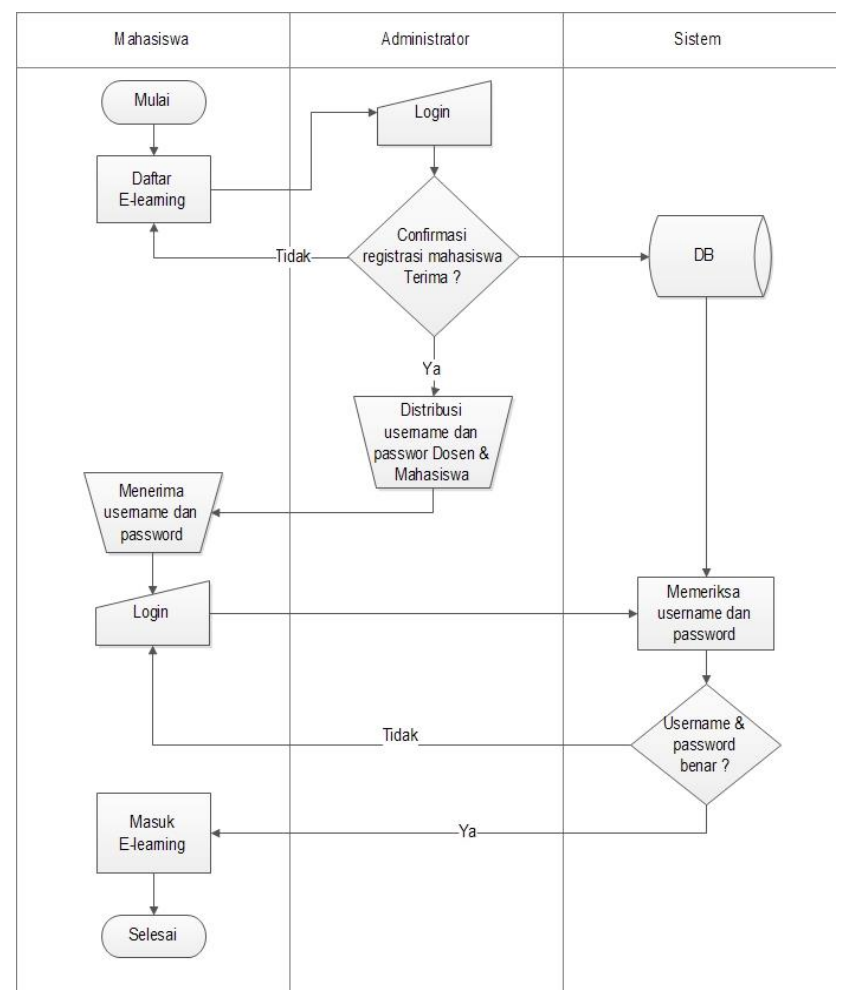

Gambar 2. Flowchart sistem yang diusulkan untuk proses log in E-learning untuk mahasiswa 
[E-ISSN 2656-0321]

[Vol 13. No. 1]

JURNAL TEKNOLOGI INFORMASI

[Januari 2019]

Jurnal Keilmutun dan Aplikasi Bidang Teknik Informatilka

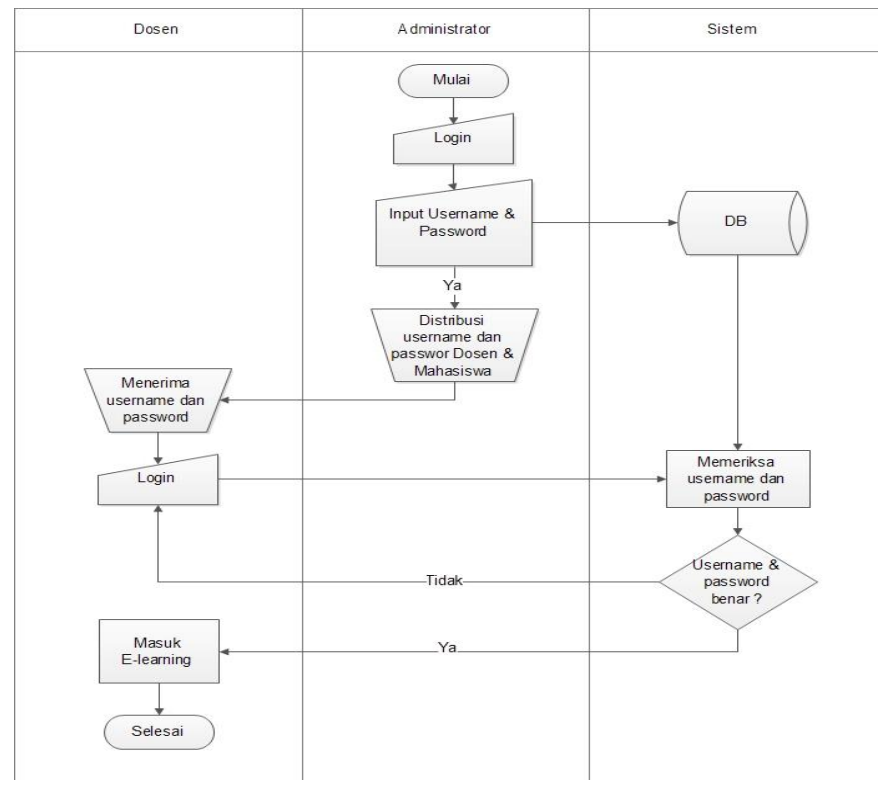

Gambar 3. Flowchart sistem yang diusulkan untuk proses log in E-learning untuk dosen

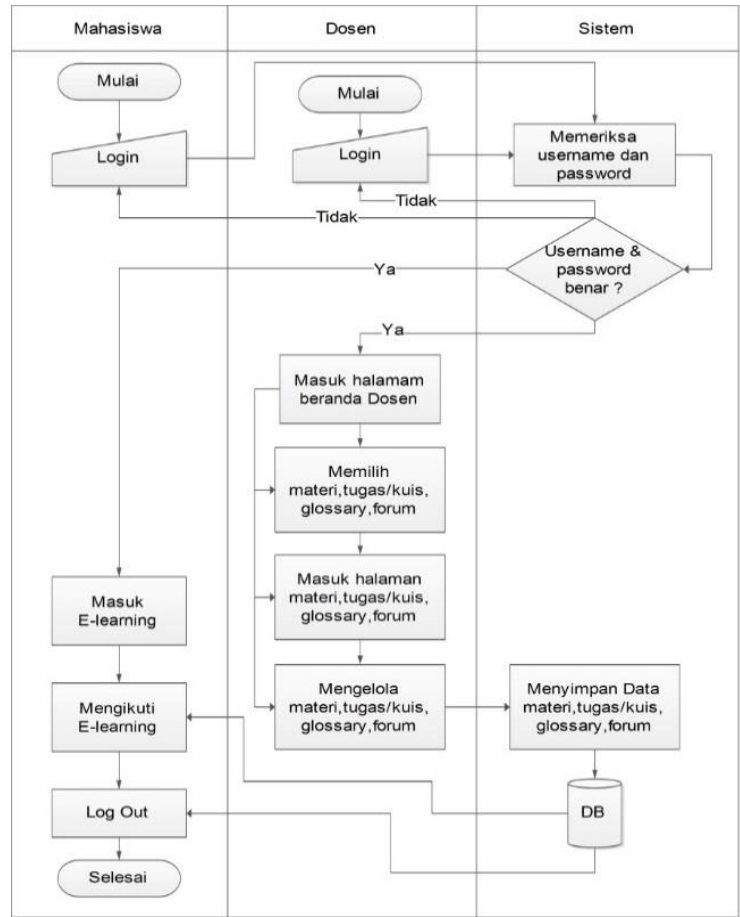

Gambar 4. Flowchart sistem yang diusulkan untuk proses mengikuti E-Learning 


\section{JURNAL TEKNOLOGI INFORMASI}

[E-ISSN 2656-0321]

[Vol 13. No. 1]

Jurnal Keeilmuan dan Aplikasi Bidang Teknilk Informatika

\subsection{Desain Sistem}

Pada bagian ini berisi rancangan dasar website e-learning yang akan dibuat sesuai dengan sasaran awal program. Selain itu analisis sistem disini menggunakan Data Flow Diagram dan Entity Relationship Diagram yang dibuat dapat di dokumentasi dengan baik dan jelas.

\subsubsection{Diagram Konteks (Context Diagram)}

Pemodelan Sistem menggunakan DFD diawali dengan pembuatan Diagram Konteks, dalam diagram ini akan terlihat proses bisnis yang terjadi dan menunjukkan entitas yang akan memberikan dan menerima informasi ke sistem (Gambar 5).

\subsubsection{Data Flow Diagram (DFD)}

DFD (Data Flow Diagram) akan menjelaskan bagaimana sistem yang akan dibuat bekerja terutama akan menjelaskan aliran data dari satu proses ke proses yang lainnya melalui beberapa tahapan, seperti berikut (Gambar 6).

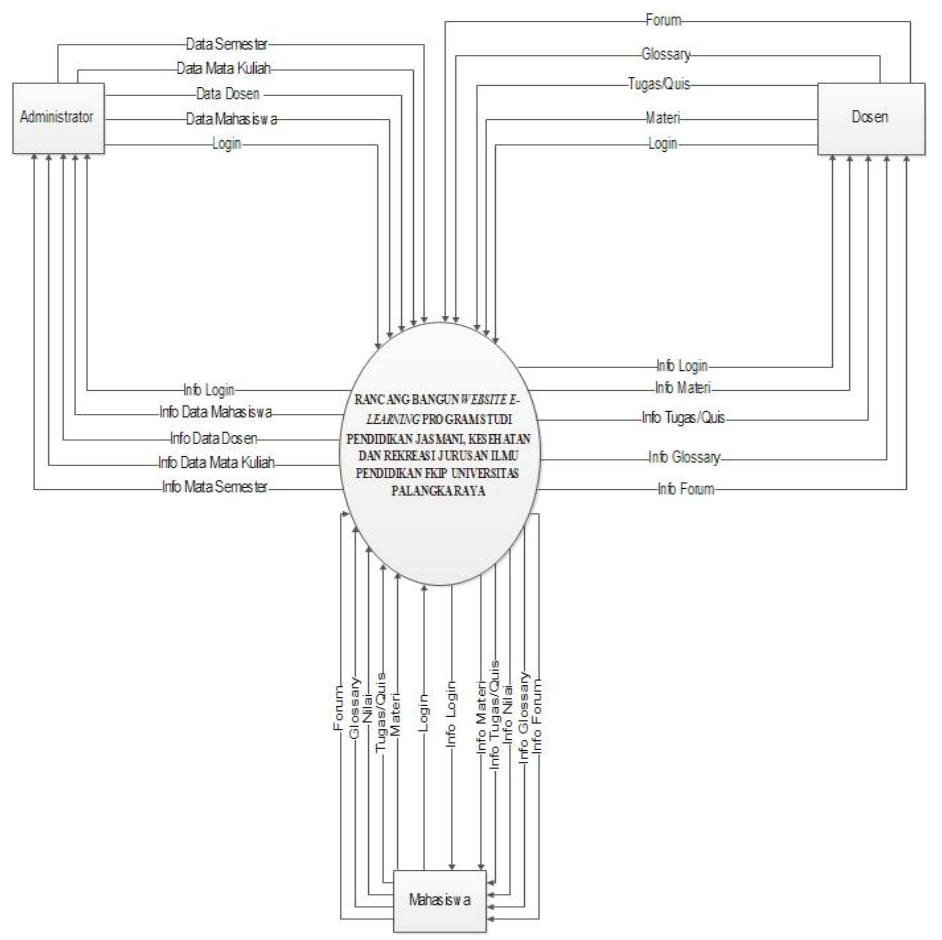

Gambar 5. Diagram Konteks 


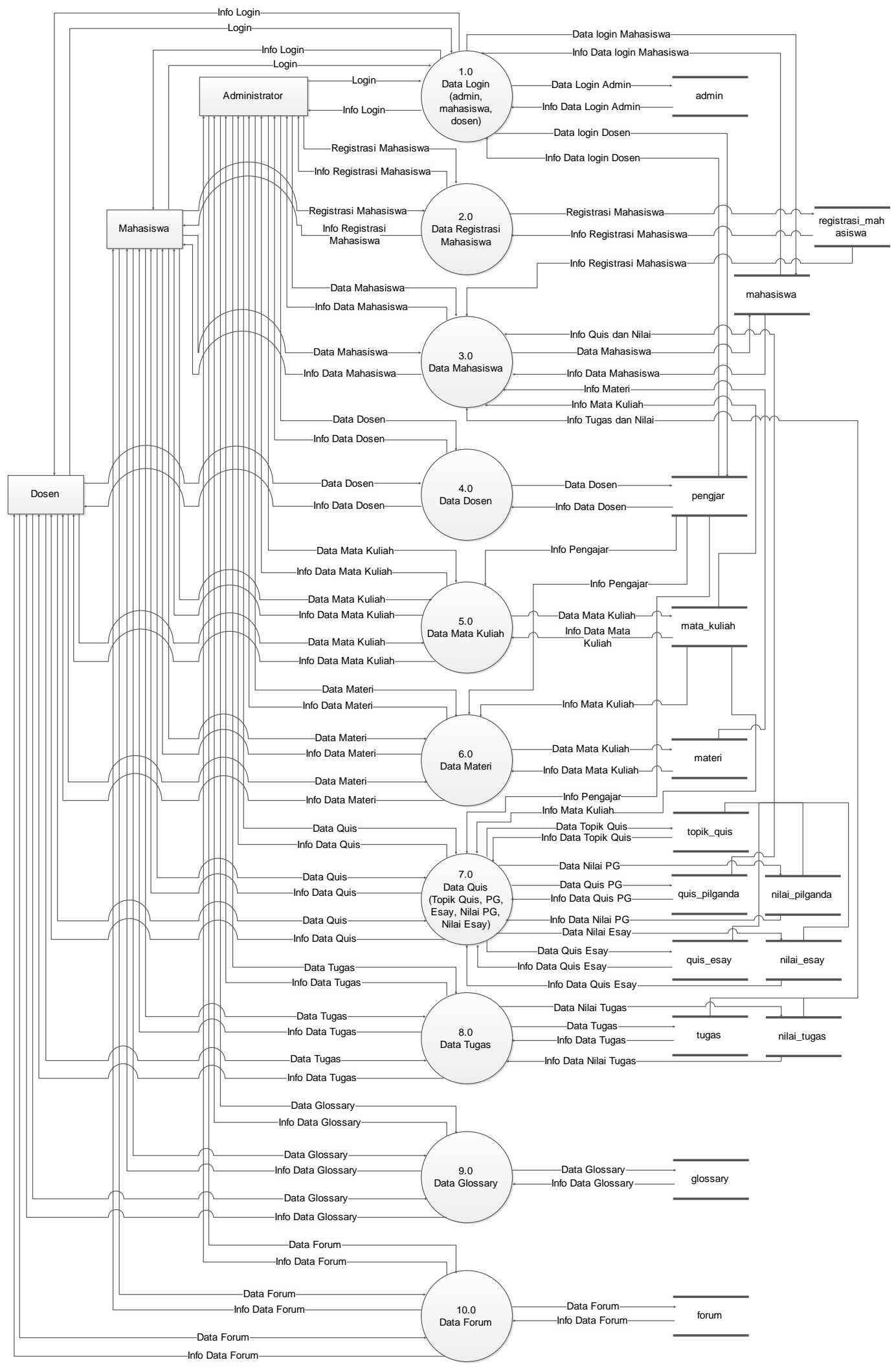

Gambar 6. DFD Level 0 
[E-ISSN 2656-0321]

[Vol 13. No. 1]

\subsubsection{Desain Navigasi Admin}

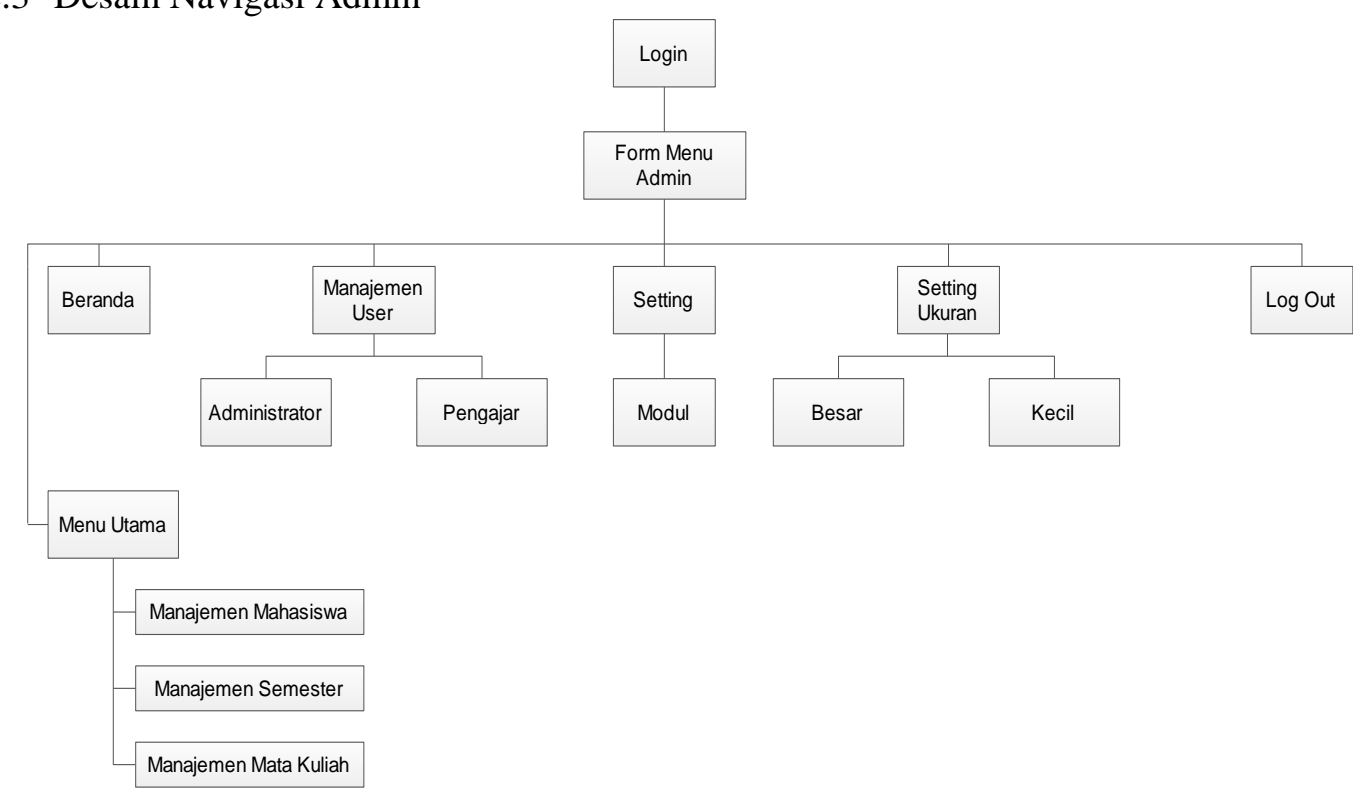

Gambar 7. Navigasi Admin

3.2.4 Navigasi Mahasiswa

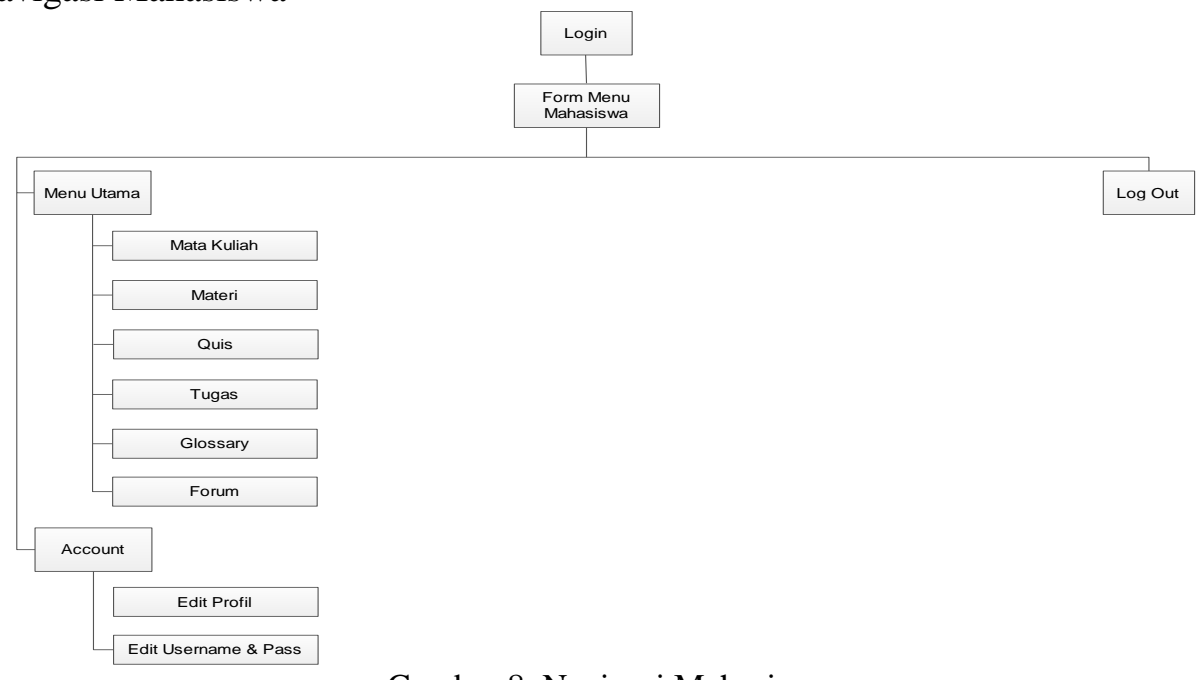

Gambar 8. Navigasi Mahasiswa 


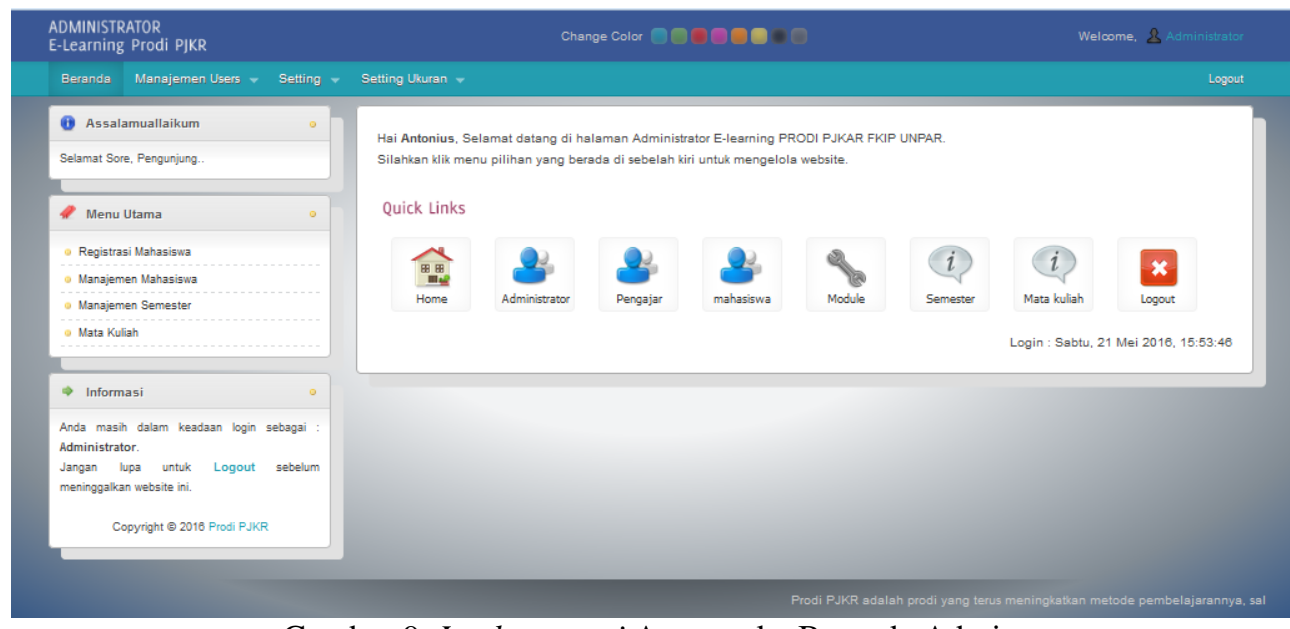

Gambar 9. Implementasi Antarmuka Beranda Admin

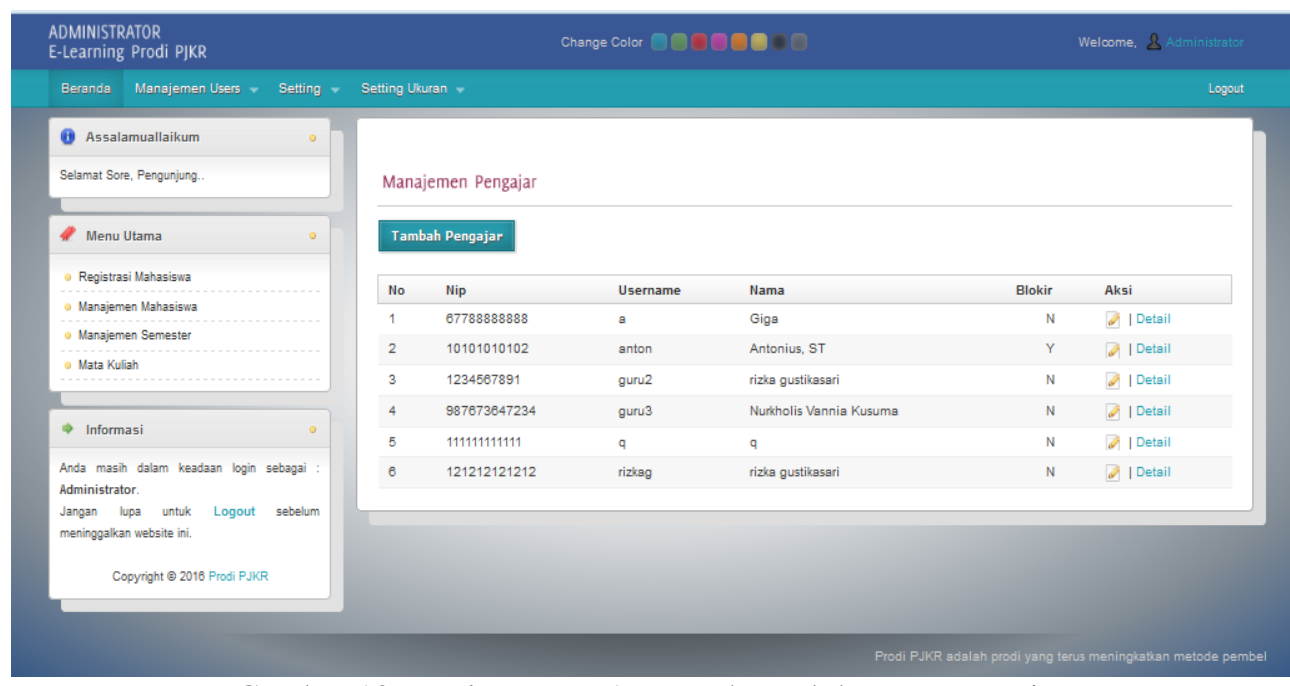

Gambar 10. Implementasi Antarmuka Kelola Data Pengajar

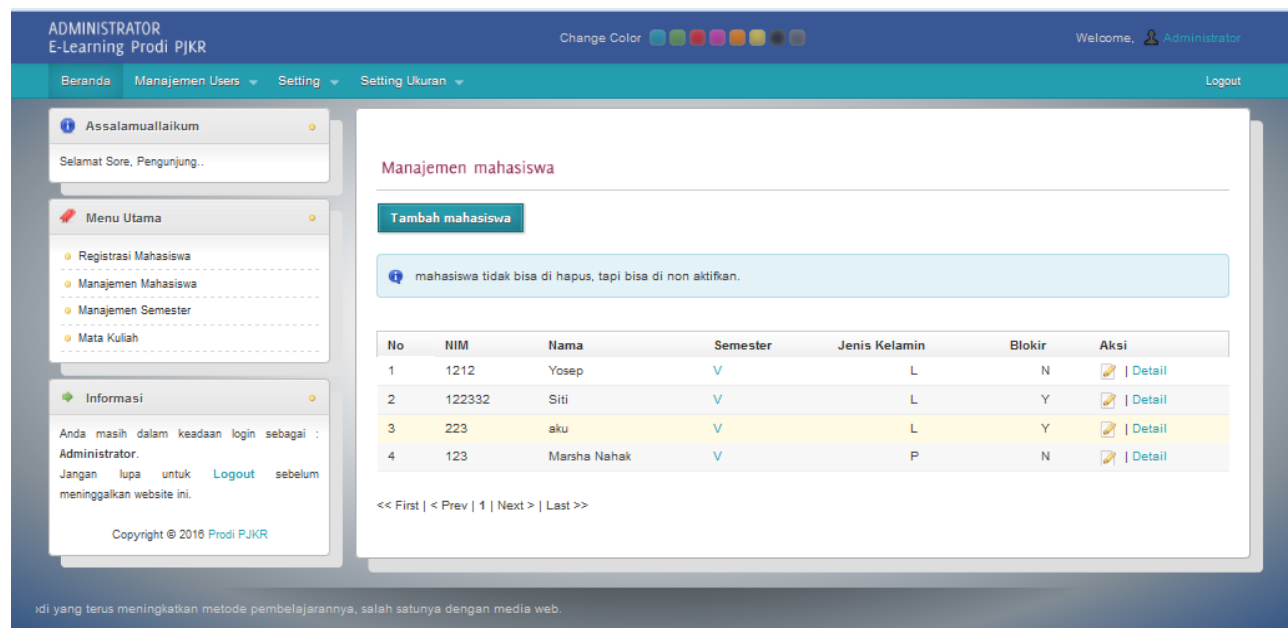

Gambar 11. Implementasi Antarmuka Kelola Mahasiswa(i) 


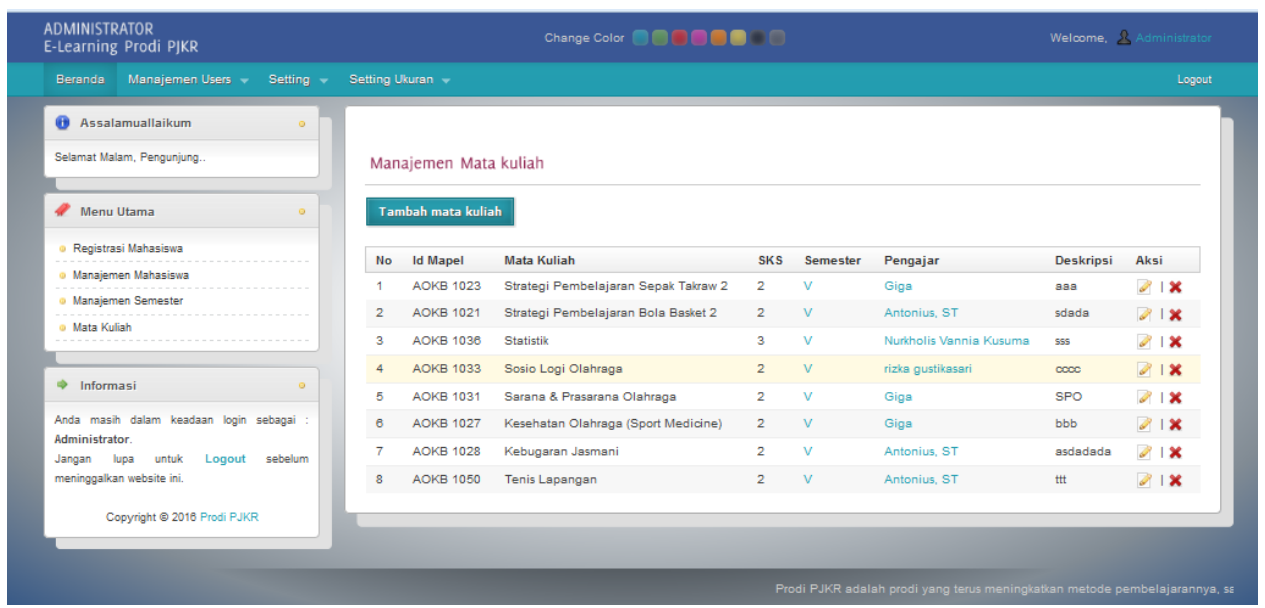

Gambar 12. Implementasi Antarmuka Kelola Data Mata Kuliah

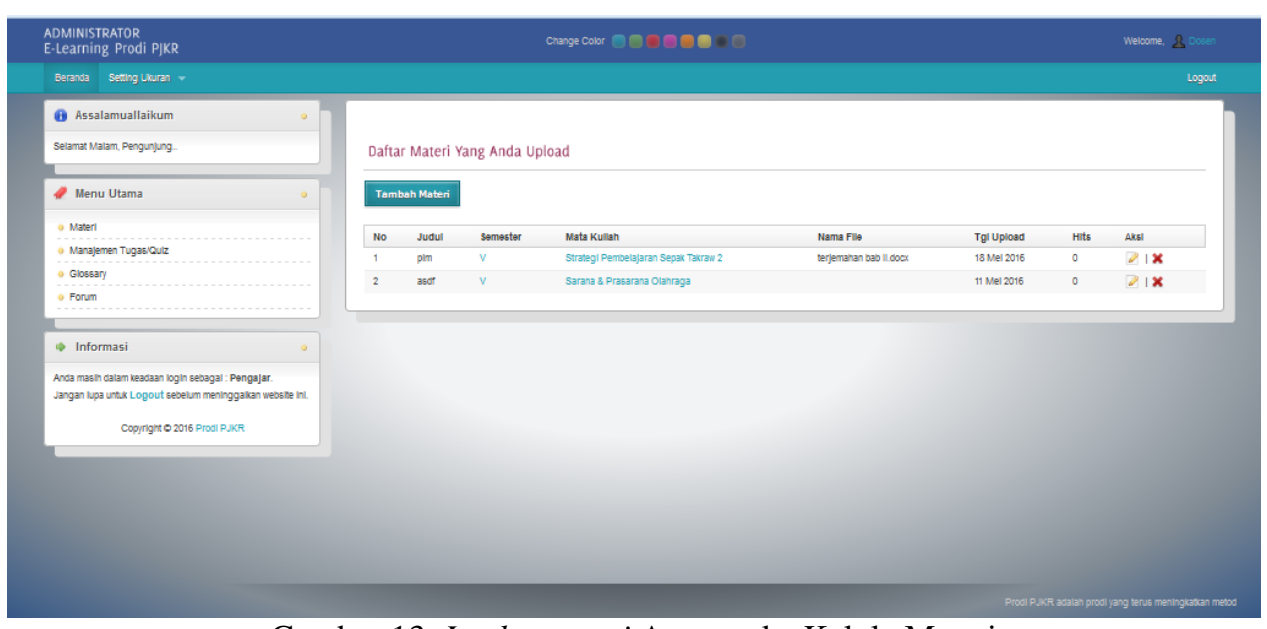

Gambar 13. Implementasi Antarmuka Kelola Materi

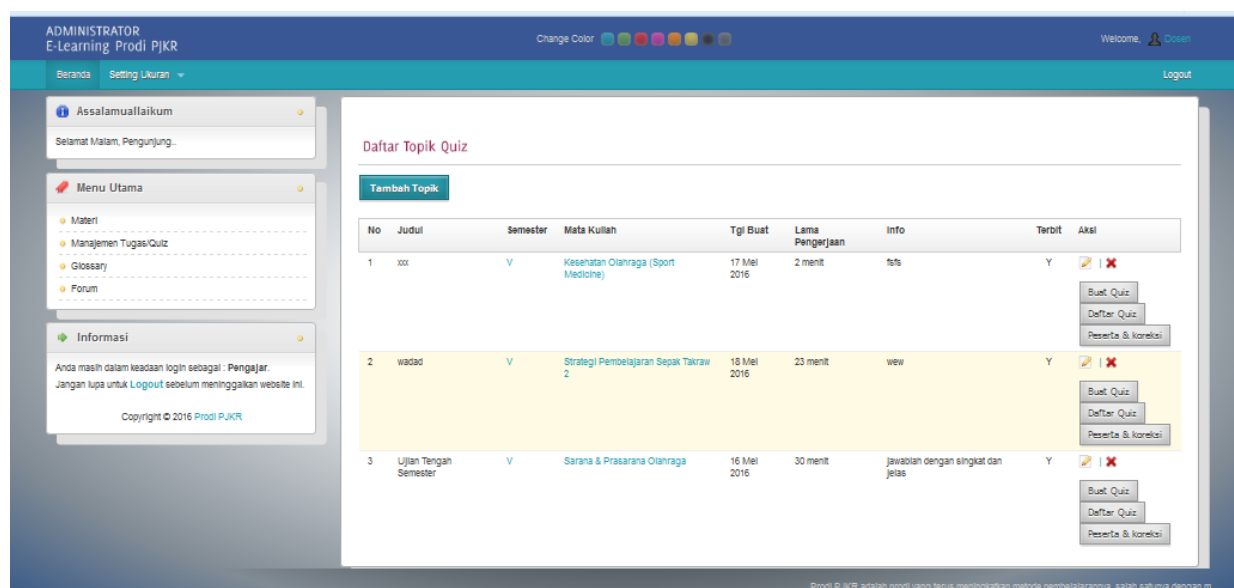

Gambar 14. Implementasi Antarmuka Kelola Tugas/Quiz 


\section{Kesimpulan Dan Saran}

\subsection{Kesimpulan}

Dari pembuatan Website E-learning Program Studi Pendidikan Jasmani, Kesehatan dan Rekreasi ini dapat disimpulkan bahwa :

1. Dalam merancang dan membangun website e-learning ini penulis menggunakan metodologi pengembangan perangkat lunak Waterfall yang memiliki 4 tahapan dari 5 tahapan yaitu :

a. Requirements Analysis and Definition (Analisis dan Definisi Kebutuhan), pada tahap analisis ini dilakukan pembuatan flowchart proses bisnis lama, dan flowchart proses bisnis untuk sistem yang dikembangkan/ diusulkan.

b. System and Software Design (Perancangan Sistem dan Perangkat Lunak), pada tahap tahap ini desain yang digunakan yaitu :

1. Desain database meng-gunakan Entity Relation-ship Diagram (ERD). Terdiri dari 16 Tabel yaitu: Tabel Admin, Tabel mahasiswa, Tabel Pengajar, Tabel mata kuliah, Tabel semester, Tabel file_materi, Tabel topik quiz, Tabel quiz_pilganda, Table quiz_esay, Tabel mahasiswa_sudah_mengerjakan, Tabel jawaban, Tabel nilai, Tabel nilai_soal_esay, Tabel Glossary, Tabel Forum, Tabel balasan

2. Desain Perancangan menggunakan Data Flow Diagram (DFD).

c. Implementation and Unit System (Implementasi dan Pengujian Unit), Desain program diterjemahkan ke dalam kode-kode dengan menggunakan bahasa pemrograman yaitu HTML, PHP, CSS, Javascript dan MySQL

d. Integration and System Testing (Integrasi dan Pengujian Sistem), pada pengujian website ELearning ini menggunakan pengujian black box.

2. Fasilitas yang disediakan dalam website E-Learning ini adalah menyediakan fitur materi, tugas/kuis yang dikhususkan untuk mahasiswa yang mengambil mata kuliah semester V.

\subsection{Saran}

Saran perbaikan yang dapat diberikan untuk kelengkapan Website E-Learning untuk Program Studi Pendidikan Jasmani, Kesehatan dan Rekreasi Jurusan Ilmu Pendidikan Fakultas Keguruan dan Ilmu Pendidikan Universitas Palangka Raya, adalah sebagai berikut;

1. Seyogyanya bisa digabungkan kedalam sistem informasi akademik sehingga sistem penilaian dapat langsung diperbaharui kedalam Kartu Hasil Studi (KHS) dan pendataan mahasiswa dapat lebih terorganisir.

2. Diperlukan pemeliharaan yang berkelanjutan sehingga website ini dapat memiliki manfaat yang optimal untuk pembelajaran online yang lebih baik.

\section{DAFTAR PUSTAKA}

[1] Harto, Tri Fajar, 2018. Sejarah dan Perkembangan E-Learning http://www.academia.edu/34533012/sejarah_dan_perkembangan_e-learning (1 September 2018)

[2] Nurma Anisa Rahmaning Tiyas, 2018. http://www.academia.edu/ 6432490/Sejarah_E-Learning (1 September 2018).

[3] http://www.leerbeleving.nl/wbts/ 1/history_of_elearning.html (1 September 2018)

[4] Bullen M. (2001), E-Learning And The Internationalization Education. Malaysian Journal of Educational Technology 1(1), 37-46

[5] Koran, Jaya Kumar C., 2002. Aplikasi E-Learning dalam Pengajaran dan Pembelajaran di Sekolah Malaysia. (8 November 2002).

[6] Tri Amri Wijaya. 2014. Rancang Bangun E-Learning 2.0 Berbasis Website Pada Balai Pengembangan Tenaga Kerja (BPTK) Djogja Bhakti Utama, Skripsi, Fakultas Teknik. Universitas Palangka Raya, Palangka Raya. 
[7] Erwin Marantika dan Ridwan Syandy. 2010, Rancang Bangun E-learning Berbasis Web Untuk Mahasiswa Teknik Informatika, Skripsi, Fakultas Teknik. Universitas Palangka Raya, Palangka Raya.

[8] Anggoro.W. B. 2005. Penerapan E-Learning Sebagai Langkah Universitas Islam Indonesia Meningkatkan Kualitas Dan Efektivitas Penyelenggaraan Pendidikan Konvensional. Lomba Karya Tulis Ilmiah. Yogyakarta. Universitas Islam Indonesia.

[9] Beam, P. (1997), Breaking the sprinter's Wrist: Acheving Cost-Effectiveness in Online Learning. Paper Presented at the International Symposium on Distance Education and open Learning, organized by MONE Indonesia, IDLN, SEAMOLEC, ICDE, UNDP and Unesco Tuban, Bali, Indonesia. 